\title{
Kajian Kuat Tekan Sejajar Serat dan Kuat Geser Kayu Tembusu (Fragraea Fragrans) di Pekanbaru Terhadap SNI 7973:2013
}

\author{
Intan Monica.MG ${ }^{1}$, Alfian Kamaldi ${ }^{2}$, Andre Novan ${ }^{3}$ \\ ${ }^{1,2,3}$ Program Studi S1 Teknik Sipil, Fakultas Teknik, Universitas Riau \\ Kampus Bina Widya Jl. HR. Soebrantas Km 12,5 Pekanbaru, Kode 28293 \\ Email : intan.monicamg@student.unri.ac.id
}

\begin{abstract}
ABSTRAK
Kayu adalah bahan yang umum digunakan baik secara struktural maupun non-struktural. Penggunaan kayu dalam bentuk struktural memerlukan spesifikasi tertentu. Kayu adalah bahan alami yang pertumbuhannya dipengaruhi oleh faktor lingkungan yang menyebabkan perbedaan kualitas kayu. Penelitian ini bertujuan untuk menguji dan memperoleh nilai kuat tekan sejajar serat kayu dan kuat geser kayu serta mengklasifikasikan kayu berdasarkan SNI 7973: 2013. Kayu tembusu (Fragraea fragrans) digunakan sebagai objek dalam penelitian ini. Hasil pengujian diperoleh nilai kuat tekan paralel kayu tembusu variasi A 16,31 MPa sehingga termasuk dalam kategori kayu dengan kode mutu E19. Nilai kuat tekan sejajar serat kayu kayu tembusu variasi B 16,26 MPa sehingga termasuk dalam kategori kayu dengan kode mutu E18. Modulus elastisitas kayu tembusu variasi A yang diperoleh adalah 3.555,95 MPa dan 5.324,24 MPa untuk variasi B. Nilai kuat geser kayu variasi A didapat sebesar 2,54 MPa dan untuk variasi B didapat 3,27 MPa. Penelitian ini bermanfaat untuk menganalisis kuat tekan sejajar serat, kuat geser kayu dan untuk penelitian lanjutan lainnya. Hasilnya diharapkan berkontribusi pada basis data ilmiah umum sifat mekanis kayu di Indonesia dan khususnya dalam desain komponen struktural tekan dan lentur serta untuk penelitian lebih lanjut
\end{abstract}

Kata Kunci: Fragraea fragrans, kuat tekan sejajar serat kayu, modulus elastisitas tekan, kuat geser kayu, SNI 7973: 2013.

\section{ABSTRACT}

Wood was a material that commonly used both structurally and non-structurally. The used of wood in structural forms required certain specifications. Wood was a natural material that growth from the influence of external factors. Tembusu (Fragraea fragrans) was used as an object in this researched. This research aims to test and obtained the value of compressive strength parallel to wood fiber and wood shear strength and classify wood based on SNI 7973: 2013. The test results obtained the value of parallel compressive strength of tembusu wood variation A 16.31 MPa so that it was included in the wood category with the quality code E19. The parallel compressive strength wood fiber variation $B 16.26 \mathrm{MPa}$ so that it was included in the wood category with the quality code E18. Modulus elasticity of tembusu wood variation A obtained was 3,555.95 MPa and 5,324.24 $M P a$ for variation $B$. The value of shear strength variation $A$ was $2.54 \mathrm{MPa}$ and for variation $B$ it was 3.27 MPa. This research was analyzed the value compressive strength parallel to fiber, wood shear strength of tembusu wood and for other advanced research. The results are expected to contributed to the general scientific database of wood mechanical properties in Indonesia and specifically in the design of compressive and flexible structural components and for further research.

Keyword: Fragraea fragrans, parallel compressive strength, parallel modulus of elasticity, wood shear strength, SNI 7973: 2013.

Intan, Kajian Kuat Tekan Sejajar Serat Dan Kuat Geser Kayu Tembusu (Fragraea Fragrans) Di Pekanbaru Terhadap Sni 7973:2013 


\section{PENDAHULUAN}

Kayu tembusu (Fragraea fragrans) merupakan kayu yang memiliki kelas awet I dan kelas kuat II-I (PKKI 1961, 1961). Tanaman tembusu tumbuh di wilayah hutan rawa dan rawa gambut terutama di wilayah Sumatra dan Kalimantan (Rosalia, 2008). Pohon tembusu berbentuk kerucut dengan tinggi mencapai $40 \mathrm{~m}$ dan memiliki diameter hingga $1,5 \mathrm{~m}$. Pohon tembusu memiliki banyak percabangan dan daunnya selalu hijau sepanjang tahun (Junaidah, Sofyan, \& Nasrun, 2014).

Kayu merupakan bahan konstruksi alami yang berasal dari alam. Kayu tumbuh dan berkembang dipengaruhi berdasarkan faktor luar. Kondisi lingkungan yang berbeda dapat menyebabkan perbedaan pada bentuk maupun kualitas kayu. Akibatnya kualitas kayu tidak dapat dikontrol sehingga sering dijumpai perbedaan kualitas pada kayu walaupun berasal dari satu pohon.

Kayu memiliki sifat yang dapat menentukan kekuatan dan kualitas kayu. Sifat propertis kayu terbagi dua yaitu sifat fisik dan sifat mekanik. Sifat fisik merupakan sifat kayu yang dapat diamati langsung sedangkan sifat mekanik merupakan sifat kayu yang dapat diketahui dengan melakukan pengujian di laboratorium. Salah satu sifat mekanik kayu adalah kuat tekan sejajar serat kayu.

Kuat tekan sejajar serat kayu merupakan sifat penting yang digunakan untuk perencanaan kolom (komponen struktur tekan). Kuat tekan merupakan gaya yang bekerja pada satuan luas penampang yang ditinjau. Kekuatan tekan kayu mendefenisikan batas kemampuan kayu menerima beban tekan hingga kayu mengalami kerusakan.

Tujuan penelitian ini adalah untuk menguji dan mendapatkan kekuatan tekan sejajar serat kayu tembusu (Fragraea fragrans) berdasarkan SNI 033958 (1995) serta selanjutnya diklasifikasikan berdasarkan SNI 7973 (2013).

\section{METODOLOGI PENELITIAN}

\section{Benda Uji}

Pengujian kuat tekan sejajar serat kayu menggunakan bahan baku kayu tembusu yang dijual di kota Pekanbaru berukuran $5 \mathrm{~cm}$ x $5 \mathrm{~cm}$ x $20 \mathrm{~cm}$ seperti yang terlihat pada Gambar 1. Pengujian kuat geser kayu berukuran $5 \mathrm{~cm}$ x $5 \mathrm{~cm}$ x $6,3 \mathrm{~cm}$ seperti yang terlihat pada Gambar 2.

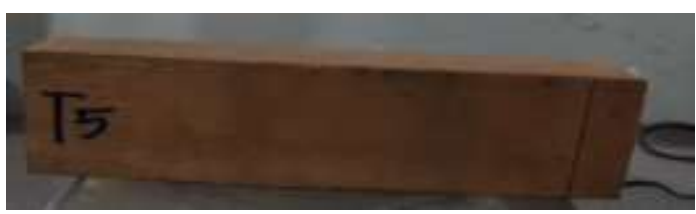

Gambar 1. Benda Uji Kuat Tekan Sejajar

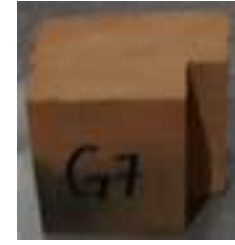

Gambar 2. Benda Uji Kuat Tekan Sejajar

\section{Variasi Pengujian}

Pengujian dilakukan dengan dua variasi benda uji yaitu variasi A dan variasi B. Benda uji variasi A merupakan benda uji yang tidak mengalami perlakuan apapun sedangkan benda uji variasi B merupakan benda uji yang mengalami perlakuan berupa pengeringan oven yang dilakukan selama 5 hari pengovenan dengan suhu $(103 \pm 2){ }^{\circ} \mathrm{C}$. jumlah benda uji adalah sebanyak tiga buah untuk setiap variasi. Sebelum dilakukan pengujian kuat tekan sejajar serat, dilakukan pengujian propertis fisik terlebih dahulu yaitu pengujian kadar air kayu.

\section{Pengujian Kadar Air}

Pengujian kadar air dilakukan dengan cara pengukuran yaitu dengan dikeringkan menggunakan oven sampai benda uji kering mutlak. Benda uji kadar air berasal dari bagian batang yang sama dengan benda uji kuat tekan yang yang mau diuji kadar airnya. Ukuran benda uji kadar air adalah $5 \mathrm{~cm}$ x $5 \mathrm{~cm}$ x $5 \mathrm{~cm}$ seperti yang terlihat pada Gambar 3 .

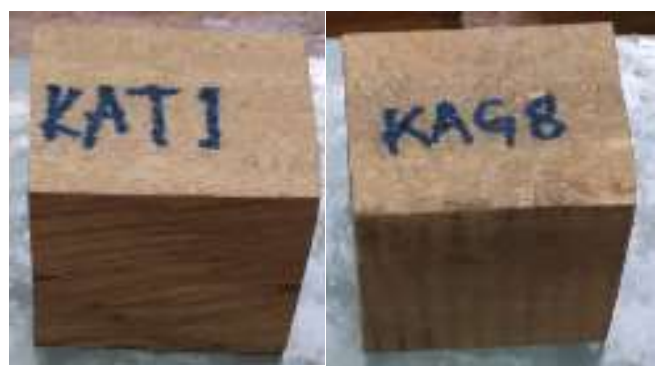

(a)

(b)

Gambar 3. (a) Benda Uji Kadar Air Kuat Tekan Sejajar Serat, (b) Benda Uji Kadar Air Kuat Geser

\section{Pengujian Kuat Tekan Sejajar Serat Kayu}

Pengujian kuat tekan sejajar serat kayu dilakukan dengan menggunakan mesin uji UTM (Universal Testing Machine) seperti yang terlihat pada Gambar 4. Mesin yang digunakan merupakan mesin dari Hung Ta dengan tipe HT-8503. Alat ini di desain untuk pengujian kuat tarik sehingga memerlukan alat bantu untuk pengujian kuat tekan berupa dudukan dengan permukaan plat yang rata seperti yang terlihat pada Gambar 5. 


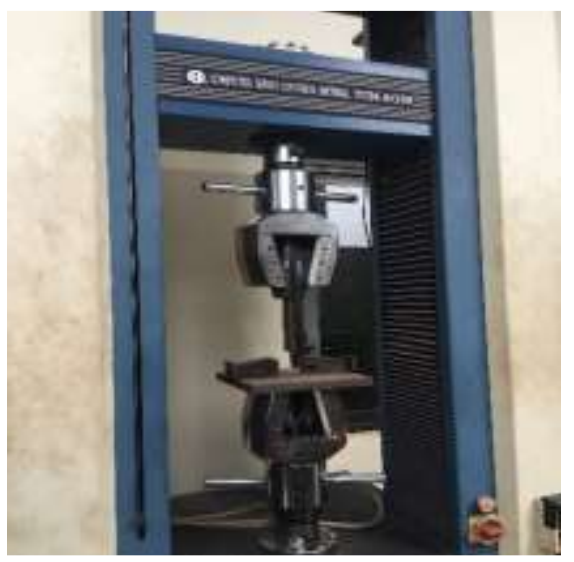

Gambar 4. Mesin UTM

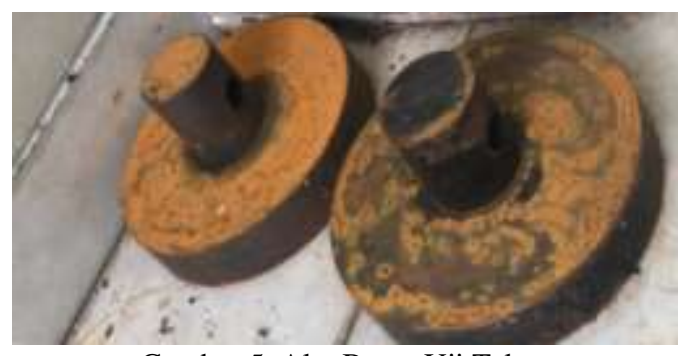

Gambar 5. Alat Bantu Uji Tekan

Pengujian kuat tekan sejajar serat kayu dilakukan seperti yang terlihat pada Gambar 6. Nilai kuat tekan sejajar kayu didapat dengan menggunakan Rumus 1 sesuai dengan SNI 03-3958-1995.

$$
F_{c}=\frac{P}{b h}
$$

Dengan:

Fc : Kuat tekan sejajar serat (MPa)

$\mathrm{P} \quad$ : Beban uji maksimum $(\mathrm{kN})$

b : Lebar benda uji (mm)

$\mathrm{h} \quad$ : Tinggi benda uji $(\mathrm{mm})$

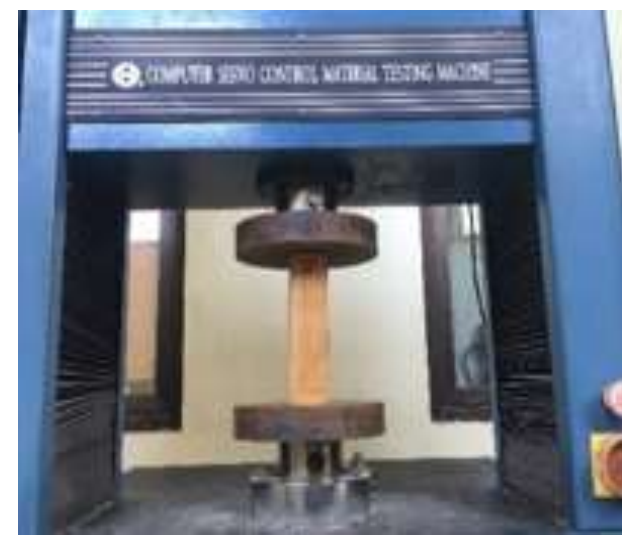

Gambar 6. Pengujian Kuat Tekan Sejajar Serat

\section{Pengujian Kuat Geser Kayu}

Pengujian kuat geser kayu dilakukan dengan menggunakan mesin uji UTM (Universal Testing Machine). Pengujian kuat geser kayu memerlukan alat bantu berupa dudukan seperti yang digunakan pada pengujian kuat tekan sejajar serat kayu dan juga pengekang yang terbuat dari plat baja sesuai ketentuan pada SNI 03-3400-1994. Pengekang kuat geser dapat dilihat pada Gambar 7.

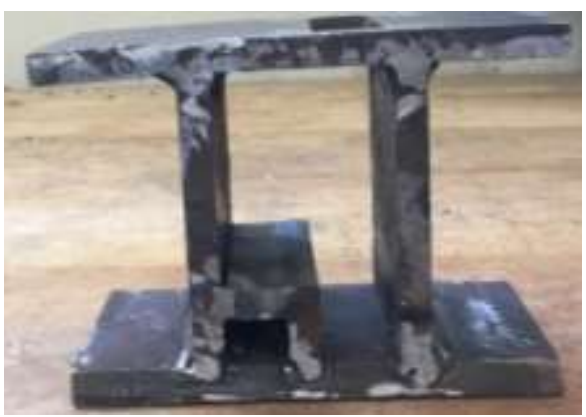

Gambar 7. Pengujian Kuat Tekan Sejajar Serat

Pengujian kuat geser kayu dilakukan seperti yang terlihat pada Gambar 8. Nilai kuat geser kayu didapat dengan menggunakan Rumus 2 sesuai dengan SNI 03-3958-1995.

$$
F_{v}=\frac{P}{b h}
$$

Dengan:

$\mathrm{F}_{\mathrm{v}} \quad$ : Kuat geser (MPa)

$\mathrm{P} \quad$ : Beban uji maksimum $(\mathrm{kN})$

b : Lebar benda uji (mm)

$\mathrm{h} \quad$ : Tinggi benda uji $(\mathrm{mm})$

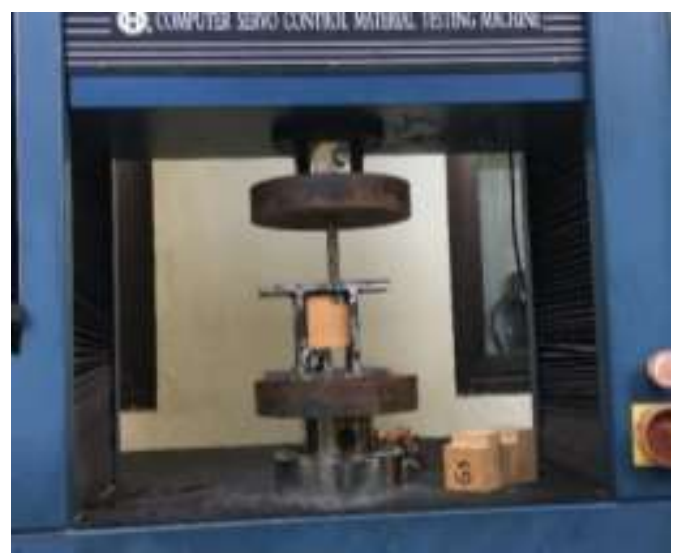

Gambar 8. Pengujian Kuat Tekan Sejajar Serat

\section{HASIL DAN PEMBAHASAN}

\section{Kadar Air}

Hasil yang didapat dari pengujian kadar air terlihat pada Tabel 1 untuk benda uji kuat tekan sejajar serat dan Tabel 2 untuk benda uji kuat geser. Benda uji variasi A ditandai dengan kode sampel A dan benda uji untuk variasi B ditandai dengan kode sampel B.

Tabel 1. Kadar Air Benda Uji Kuat Tekan Sejajar Serat Kayu 


\begin{tabular}{|c|c|}
\hline Kode Sampel & Kadar air akhir \\
& \\
\hline TA1 & $60,65 \%$ \\
TA2 & $63,20 \%$ \\
TA3 & $56,80 \%$ \\
TB5 & $26,66 \%$ \\
TB6 & $26,66 \%$ \\
TB7 & $27,15 \%$ \\
\hline
\end{tabular}

Tabel 2. Kadar Air Benda Uji Kuat Geser Kayu

\begin{tabular}{|c|c|}
\hline Kode Sampel & Kadar air akhir \\
\hline GA1 & $60,65 \%$ \\
\hline GA3 & $56,80 \%$ \\
\hline GA4 & $62,23 \%$ \\
\hline
\end{tabular}

\begin{tabular}{l|l|} 
GB5 & $4,14 \%$ \\
GB7 & $3,84 \%$ \\
GB8 & $1,73 \%$ \\
\hline
\end{tabular}

\section{Kuat Tekan Sejajar Serat Kayu}

Hasil yang didapat dari pengujian kuat tekan sejajar serat untuk variasi A berupa grafik hubungan antara tegangan dan regangan yang terdapat pada Gambar 9 untuk variasi A dan Gambar 10 untuk variasi B. Hasil pengujian kemudian diubah dalam bentuk grafik hubungan beban vs. deformasi dengan membagikan tegangan yang dihasilkan terhadap luas permukaan bidang yang selanjutnya dianalisis untuk menghitung kuat tekan sejajar serat seperti yang terdapat pada Tabel 3 untuk variasi A dan Tabel 4 untuk variasi B. Data yang digunakan berupa nilai beban maksimum pada setiap benda uji. Kuat tekan yang didapat berupa kuat tekan ultimit benda uji yang didapat dari perbandingan nilai beban maksimum terhadap luas penampang benda uji. Nilai kuat tekan sejajar serat ultimit kemudian dibagi dengan nilai konversi format $\left(\mathrm{K}_{\mathrm{F}}\right)$ sehingga didapat nilai kuat tekan sejajar serat izin kayu.

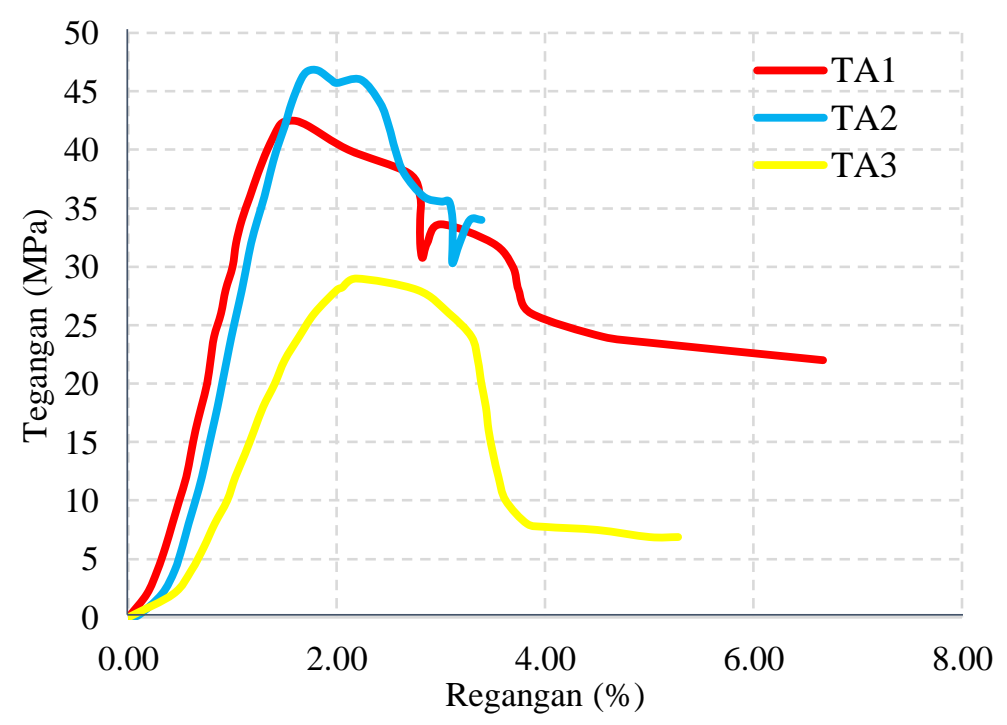

Gambar 9. Kurva Hubungan Tegangan dan Regangan Tekan Sejajar Serat Variasi A

Tabel 3. Hasil Analisis Pengujian Kuat Tekan Sejajar Serat Variasi A

\begin{tabular}{|c|c|c|c|c|c|}
\hline $\begin{array}{c}\text { No. } \\
\text { Kode }\end{array}$ & $\begin{array}{c}\text { Area } \\
\left(\mathrm{mm}^{2}\right)\end{array}$ & $\begin{array}{c}\text { Beban } \\
\text { Maksimum } \\
(\mathrm{N})\end{array}$ & $\begin{array}{c}\mathrm{F}_{\mathrm{C}} \text { Ultimit } \\
(\mathrm{Mpa})\end{array}$ & $\mathrm{K}_{\mathrm{F}}$ & $\mathrm{F}_{\mathrm{C}}$ Izin (Mpa) \\
\hline TA1 & $2.521,50$ & $107.073,60$ & 42,46 & & \\
TA2 & $2.688,40$ & $123.698,20$ & 46,01 & 2,40 & 17,69 \\
TA3 & $2.659,98$ & $77.102,20$ & 28,99 & & 12,08 \\
\hline \multicolumn{7}{|c|}{ Fc Izin Rata-rata $=$} & 16,31 \\
\hline
\end{tabular}




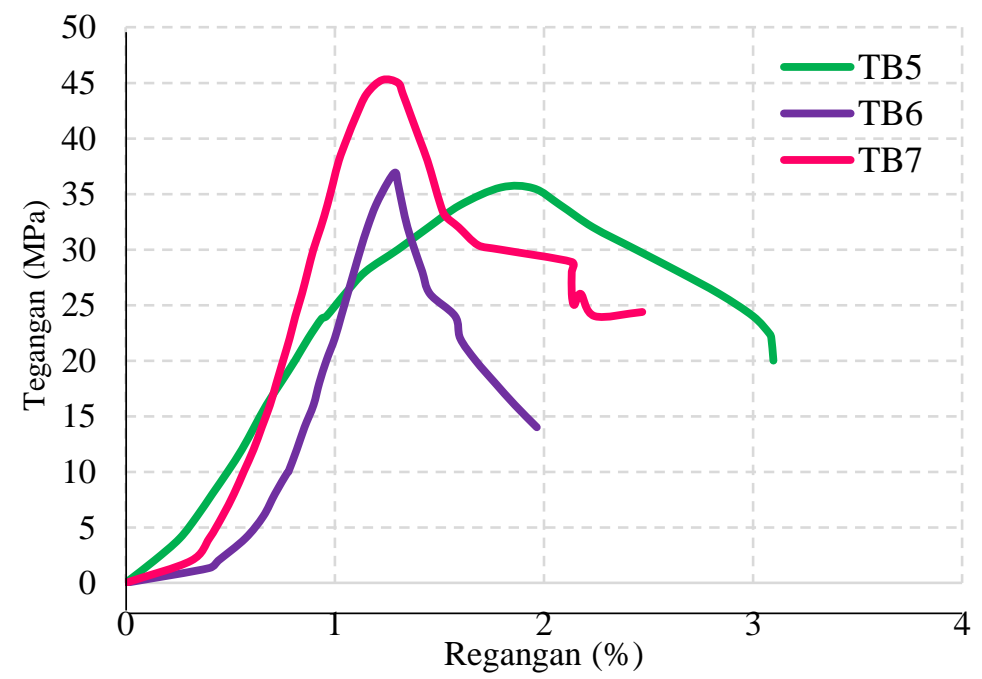

Gambar 10. Kurva Hubungan Tegangan dan Regangan Tekan Sejajar Serat Variasi B

Tabel 4. Hasil Analisis Pengujian Kuat Tekan Sejajar Serat Variasi B

\begin{tabular}{|c|c|c|c|c|c|}
\hline $\begin{array}{c}\text { Kode } \\
\text { Sampel }\end{array}$ & $\begin{array}{c}\text { Area } \\
\left(\mathrm{mm}^{2}\right)\end{array}$ & $\begin{array}{c}\text { Beban } \\
\text { Maksimum } \\
(\mathrm{N})\end{array}$ & $\begin{array}{c}\mathrm{F}_{\mathrm{C}} \text { Ultimit } \\
(\mathrm{MPa})\end{array}$ & $\mathrm{K}_{\mathrm{F}}$ & F \\
\hline TB5 & $2.590,77$ & $91.461,40$ & 35,30 & & 14,71 \\
TB6 & $2.570,45$ & $94.157,40$ & 36,63 & 2,40 & 15,26 \\
TB7 & $2.583,15$ & $116.547,60$ & 45,12 & & 18,80 \\
\hline \multicolumn{5}{|c|}{ Fc Izin Rata-rata $=$} & 16,26 \\
\hline
\end{tabular}

Dari hasil pengujian rata-rata kuat tekan sejajar serat berdasarkan SNI 03-3958-1995 diperoleh nilai kuat tekan sejajar serat rata-rata untuk benda uji variasi A yaitu 16,31 MPa, lebih besar dari pada nilai kuat tekan sejajar serat rata-rata untuk benda uji variasi B yaitu 16,26 MPa. Berdasarkan SNI 7973:2013, nilai kuat tekan sejajar serat untuk variasi A termasuk mutu kayu E19 sedangkan nilai kuat tekan sejajar serat untuk variasi A termasuk mutu kayu E18.

\section{Modulus Elastisitas Tekan Kayu}

Modulus elastisitas tekan kayu merupakan perbandingan antara tegangan dan regangan kayu akibat pengujian kuat tekan sejajar serat kayu. Analisis modulus elastisitas tekan kayu dapat dilihat pada Gambar 11 untuk variasi A dan Gambar 12 untuk variasi $\mathrm{B}$. 


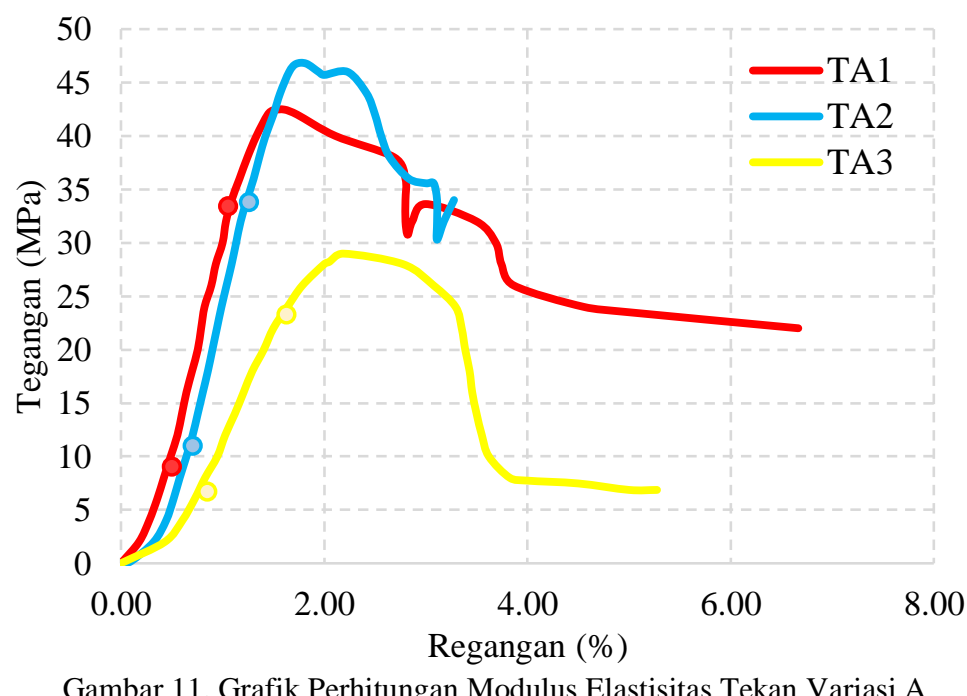

Berdasarkan Gambar 11 nilai modulus elastisitas tekan benda uji TA1 dihitung dengan menggunakan data pada tegangan $10 \mathrm{MPa}$ dengan regangan 0,49 dan $34 \mathrm{MPa}$ dengan regangan 1,09. Nilai modulus elastisitas tekan benda uji TA2 dihitung dengan menggunakan data pada tegangan 12 $\mathrm{MPa}$ dengan regangan 0,71 dan $34 \mathrm{MPa}$ dengan

regangan 1,24. Nilai modulus elastisitas tekan benda uji TA3 dihitung dengan menggunakan data pada tegangan $8 \mathrm{MPa}$ dengan regangan 0,83 dan $24 \mathrm{MPa}$ dengan regangan 1,64. Perhitungan modulus elastisitas kayu dapat dilihat pada Tabel 5 untuk variasi $\mathrm{A}$.

Tabel 5. Perhitungan Modulus Elastisitas Tekan Variasi A

\begin{tabular}{|c|c|c|c|c|c|c|c|}
\hline $\begin{array}{c}\text { No. } \\
\text { Kode }\end{array}$ & $\begin{array}{c}\sigma_{1} \\
(\mathrm{MPa})\end{array}$ & $\begin{array}{c}\sigma_{2} \\
(\mathrm{MPa})\end{array}$ & $\varepsilon_{1} \times 10^{-2}$ & $\varepsilon_{2} \times 10^{-2}$ & $\begin{array}{c}\Delta \sigma \\
(\mathrm{MPa})\end{array}$ & $\Delta \varepsilon \times 10^{-2}$ & $\begin{array}{c}\mathrm{E} / / \\
(\mathrm{MPa})\end{array}$ \\
\hline TA1 & 10,00 & 34,00 & 0,49 & 1,09 & 24 & 0,60 & $3.999,41$ \\
TA2 & 12,00 & 34,00 & 0,71 & 1,24 & 22 & 0,53 & $4.125,03$ \\
TA3 & 8,00 & 24,00 & 0,83 & 1,64 & 16 & 0,81 & $1.974,33$ \\
\hline \multicolumn{7}{|c|}{ E Rata-rata $=$} & $3.555,95$ \\
\hline
\end{tabular}

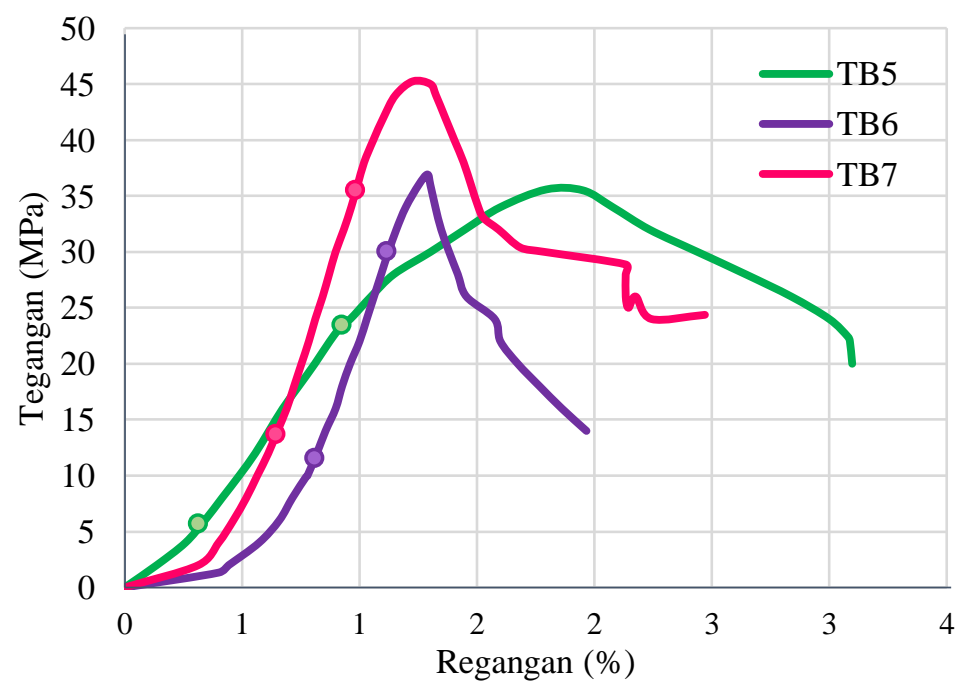

Gambar 12. Grafik Perhitungan Modulus Elastisitas Tekan Variasi B

Berdasarkan Gambar 12 nilai modulus elastisitas tekan benda uji TB5 dihitung dengan menggunakan data pada tegangan $6 \mathrm{MPa}$ dengan regangan 0,34 dan 23,76 $\mathrm{MPa}$ dengan regangan 0,94. 
Nilai modulus elastisitas tekan benda uji TB6 dihitung dengan menggunakan data pada tegangan 12 $\mathrm{MPa}$ dengan regangan 0,82 dan $30 \mathrm{MPa}$ dengan regangan 1,12. Nilai modulus elastisitas tekan benda uji TB7 dihitung dengan menggunakan data pada tegangan $14 \mathrm{MPa}$ dengan regangan 0,65 dan $36 \mathrm{MPa}$ dengan regangan 0,99 . Perhitungan modulus elastisitas kayu dapat dilihat pada Tabel 6 untuk variasi $\mathrm{B}$.

Tabel 6. Perhitungan Modulus Elastisitas Tekan Kayu Variasi B

\begin{tabular}{|c|c|c|c|c|c|c|c|}
\hline $\begin{array}{c}\text { No. } \\
\text { Kode }\end{array}$ & $\begin{array}{c}\sigma_{1} \\
(\mathrm{MPa})\end{array}$ & $\begin{array}{c}\sigma_{2} \\
(\mathrm{MPa})\end{array}$ & $\varepsilon_{1} \times 10^{-2}$ & $\varepsilon_{2} \times 10^{-2}$ & $\begin{array}{c}\Delta \sigma \\
(\mathrm{MPa})\end{array}$ & $\Delta \varepsilon \times 10^{-2}$ & $\begin{array}{c}\mathrm{E} / / \\
(\mathrm{MPa})\end{array}$ \\
\hline TB5 & 6,00 & 23,76 & 0,34 & 0,94 & 17,76 & 0,60 & $2.984,61$ \\
TB6 & 12,00 & 30,00 & 0,82 & 1,12 & 18 & 0,30 & $5.911,33$ \\
TB7 & 14,00 & 36,00 & 0,65 & 0,99 & 22 & 0,34 & $6.489,68$ \\
\hline \multicolumn{78}{|c|}{ E Rata-rata $=$} & $5.324,24$ \\
\hline
\end{tabular}

Berdasarkan Tabel 4 dan Tabel 5 didapat nilai modulus elastisitas tekan kayu untuk benda uji variasi A yaitu 3.555,95 $\mathrm{MPa}$ sedangkan nilai modulus elastisitas tekan untuk benda uji variasi $\mathrm{B}$ memiliki nilai yang lebih besar yaitu 5.324,24 MPa.

\section{Kuat Geser Kayu}

Hasil yang didapat dari pengujian kuat geser untuk variasi A berupa grafik hubungan antara tegangan dan regangan yang terdapat pada Gambar
13 untuk variasi A dan Gambar 14 untuk variasi B. Hasil pengujian kemudian dianalisis untuk menghitung kuat geser kayu seperti yang terdapat pada Tabel 7 untuk variasi A dan Tabel 8 untuk variasi B. Kuat geser yang didapat berupa kuat tekan ultimit benda uji yang didapat dari perbandingan nilai beban maksimum terhadap luas penampang bidang geser. Nilai kuat geser ultimit kemudian dibagi dengan nilai konversi format $\left(\mathrm{K}_{\mathrm{F}}\right)$ sehingga didapat nilai kuat tekan sejajar serat izin kayu.

Tabel 7. Hasil Analisis Pengujian Kuat Geser Variasi A

\begin{tabular}{|c|c|c|c|c|c|}
\hline $\begin{array}{c}\text { Kode } \\
\text { Sampel }\end{array}$ & $\begin{array}{c}\text { Area } \\
\left(\mathrm{mm}^{2}\right)\end{array}$ & $\begin{array}{c}\text { Beban } \\
\text { Maksimum (N) }\end{array}$ & $\begin{array}{c}\mathrm{F}_{\mathrm{V}} \text { Ulitimit } \\
(\mathrm{MPa})\end{array}$ & $\mathrm{K}_{\mathrm{F}}$ & $\begin{array}{c}\text { Fv Izin } \\
(\mathrm{MPa})\end{array}$ \\
\hline GA1 & $2.649,68$ & $14.585,50$ & 5,50 & & 1,91 \\
GA3 & $2.623,95$ & $22.560,50$ & 8,60 & 2,88 & 2,99 \\
GA4 & $2.647,10$ & $20.705,30$ & 7,82 & & 2,72 \\
\hline \multicolumn{7}{|r|}{} \\
\hline
\end{tabular}

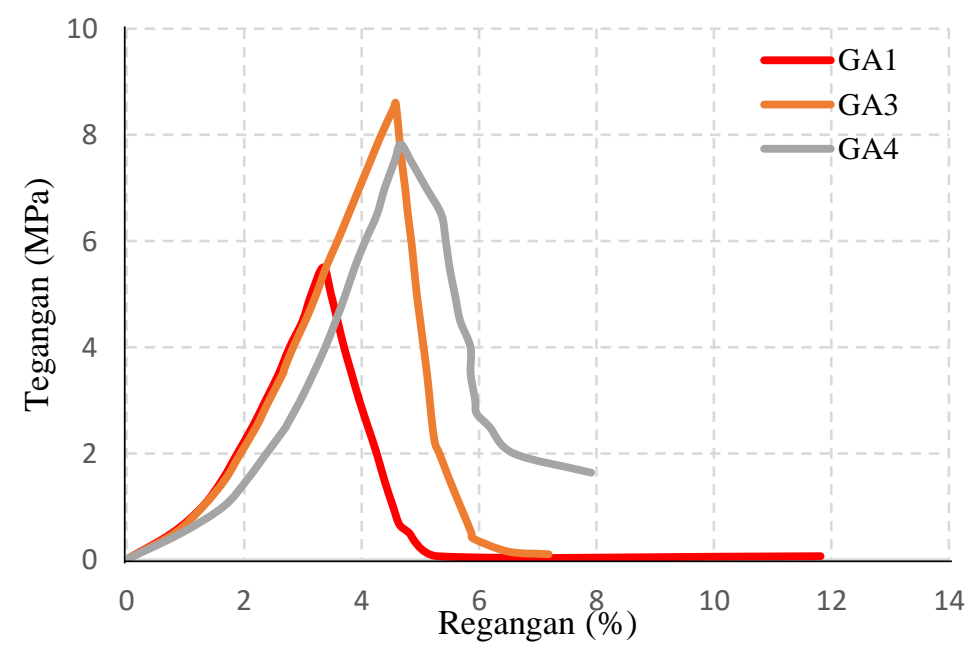

Gambar 13. Kurva Hubungan Tegangan dan Regangan Kuat Geser Variasi A

Tabel 8. Hasil Analisis Pengujian Kuat Geser Variasi B

\begin{tabular}{|l|l|l|l|l|l|}
\hline & Area & & $K_{F}$ & FV Izin \\
\hline
\end{tabular}




\begin{tabular}{|c|c|c|c|c|c|}
\hline $\begin{array}{c}\text { Kode } \\
\text { Sampel }\end{array}$ & $\left(\mathrm{mm}^{2}\right)$ & $\begin{array}{c}\text { Beban } \\
\text { Maksimum (N) }\end{array}$ & $\begin{array}{c}\mathrm{F}_{\mathrm{v}} \text { Ulitimit } \\
(\mathrm{MPa})\end{array}$ & & $(\mathrm{MPa})$ \\
\hline GKO-5 & $2.552,18$ & $23.840,90$ & 9,34 & & 3,24 \\
GKO-7 & $2.560,32$ & $13.375,10$ & 5,22 & 2,88 & 1,81 \\
GKO-8 & $2.542,58$ & $34.766,40$ & 13,67 & & 4,75 \\
\hline \multicolumn{7}{|c|}{} & \multicolumn{4}{|c|}{ Fv Rata-Rata Izin $=$} & 3,27 \\
\hline
\end{tabular}

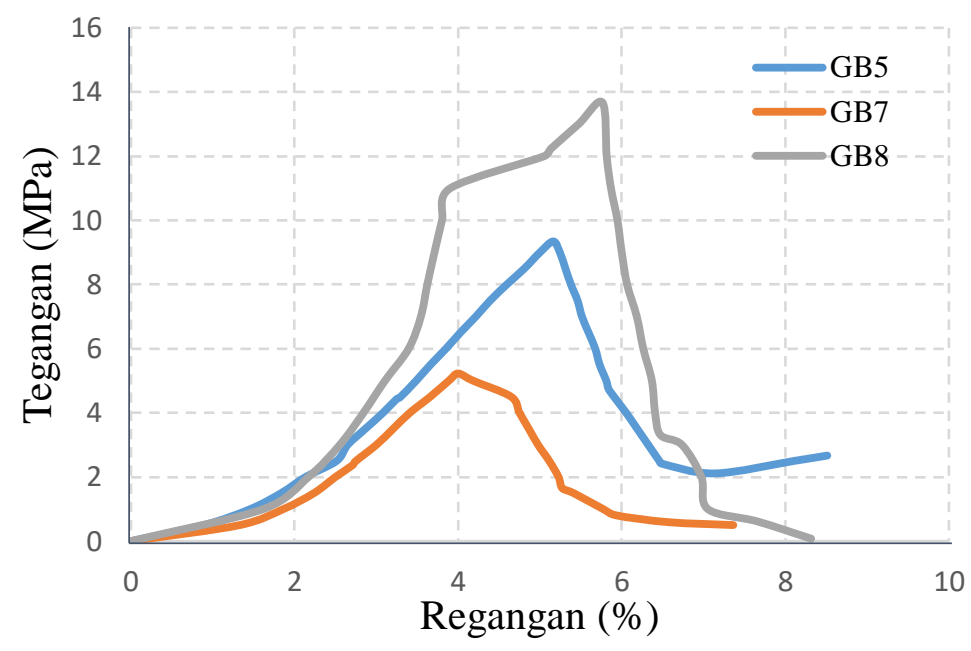

Gambar 14. Kurva Hubungan Tegangan dan Regangan Kuat Geser Variasi B

Dari hasil pengujian kuat geser didapat nilai rata-rata kuat geser benda uji variasi B yaitu sebesar 3,27 MPa lebih besar dibandingkan dengan nilai ratarata kuat geser benda uji variasi A yaitu sebesar 2,54 MPa. Berdasarkan SNI 7973:2013 nilai kuat geser benda uji variasi A termasuk kategori kayu dengan kode mutu E21 untuk parameter kuat geser, sedangkan untuk benda uji variasi B termasuk kategori kayu dengan kode mutu E25 untuk parameter kuat geser.

Tabel 9. Bentuk Keretakan Benda Uji Kuat Geser Kering Udara

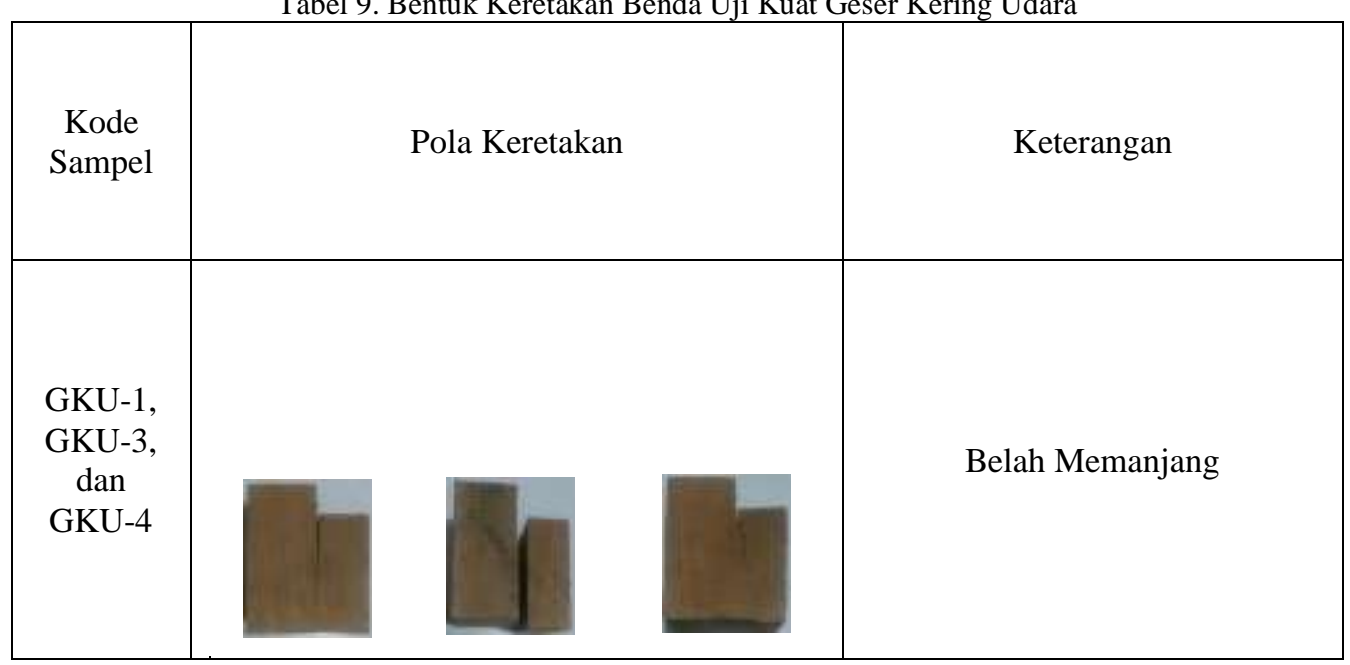


Tabel 10. Bentuk Keretakan Benda Uji Kuat Geser Kering Oven

\begin{tabular}{|c|c|c|}
\hline Kode & Pola Keretakan & Keterangan \\
Sampel & & \\
\hline & & Belah Memanjang \\
GKO-5, & GKO-7, \\
dan & & \\
GKO-8 & &
\end{tabular}

\section{Bentuk Keretakan Kayu Pengujian Kuat Tekan} Sejajar Serat

Bentuk keretakan yang terjadi bisa bervariasi tergantung kondisi benda uji, peralatan pengujian, maupun proses pengujian. Bentuk keretakan yang terjadi akibat pengujian kuat tekan sejajar serat dapat dilihat pada Tabel 11 untuk variasi A dan Tabel 12 untuk variasi $\mathrm{B}$.

Tabel 11. Bentuk Keretakan Benda Uji Kuat Tekan Sejajar Serat Variasi A

\begin{tabular}{|c|c|c|}
\hline $\begin{array}{l}\text { Kode } \\
\text { Sampel }\end{array}$ & TA1 dan TA3 & TA2 \\
\hline $\begin{array}{l}\text { Bentuk } \\
\text { Keretakan }\end{array}$ & & \\
\hline Keterangan & $\begin{array}{c}\text { Belah } \\
\text { memanjang }\end{array}$ & Retak geser \\
\hline
\end{tabular}

Bentuk keretakan yang terjadi berupa belah memanjang dan retak ujung. Belah memanjang lazim terjadi pada pengujian kuat tekan sejajar serat yang menandakan benda uji merupakan kayu keras. Kegagalan yang terjadi secara tiba-tiba menandakan kayu bersifat getas. Retak geser terjadi karena gaya geser yang terjadi pada serat kayu lebih dominan daripada gaya lainnya.

Tabel 12. Bentuk Kerusakan Benda Uji Kuat Tekan Sejajar Serat Variasi B

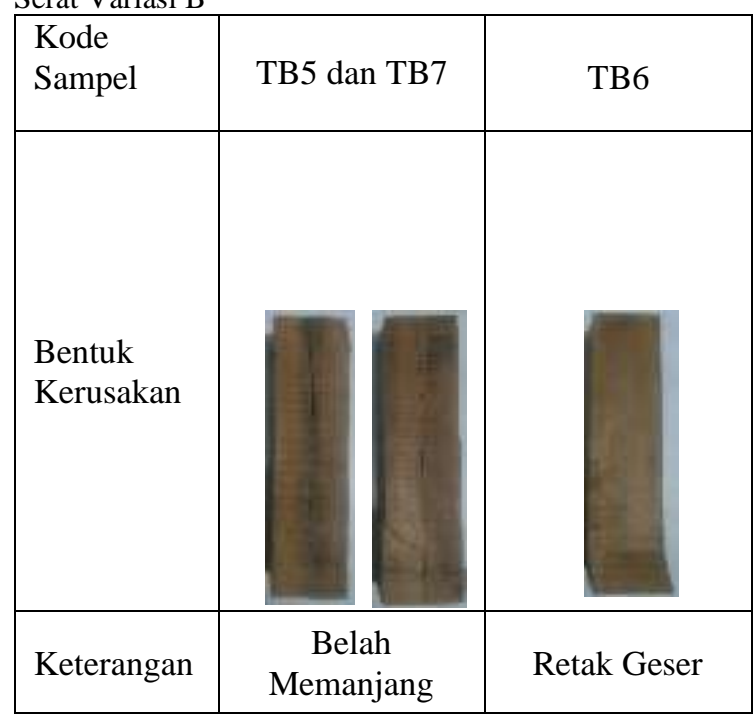




\section{KESIMPULAN}

Kekuatan tekan sejajar serat kayu tembusu untuk variasi A sebesar 16,31 MPa dan untuk variasi B sebesar 16,26 MPa. Nilai kuat tekan sejajar serat variasi A termasuk mutu kayu E19 dan untuk variasi B termasuk mutu kayu E18. Modulus elastisitas tekan kayu untuk variasi A sebesar 3.555,95 MPa dan untuk variasi B sebesar 5.324,24 MPa.

\section{DAFTAR PUSTAKA}

[1] Junaidah, Sofyan, A., \& Nasrun. (2014). Mengenal karakteristik tanaman tembesu. In N. Mindawati, H. S. Nurohmah, \& C. Akhmad (Eds.), Tembesu kayu raja andalan Sumatera (pp. 3-12). Bogor: FORDA Press.
[2] PKKI 1961. (1961). Peraturan konstruksi kayu Indonesia. Departemen Pekerjaan Umum.

[3] Rosalia, N. (2008). Penyebaran dan karakteristik tempat tumbuh pohon tembesu (Fragraea fragrans Roxb.).

[4] SNI 03-3400-1994. (1994). Metode pengujian kuat geser kayu di laboratorium. Badan Standardisasi Nasional.

[5] SNI 03-3958-1995. (1995). Metode pengujian kuat tekan kayu di laboratorium. Badan Standardisasi Nasional.

[6] SNI 7973:2013. (2013). Spesifikasi desain untuk konstruksi kayu. Badan Standardisasi Nasional. Badan Standardisasi Nasional. 